\title{
EFEKTIVITAS MANAJEMEN RISIKO PEMBIAYAAN DI BNI SYARIAH CABANG SURABAYA DALAM PENGENDALIAN PEMBIAYAAN BERMASALAH
}

\author{
Muhamad Ahsan* dan Muhammad Farid Al-Azhar \\ Universitas Islam Negeri Sunan Ampel Surabaya
}

\begin{abstract}
ABSTRAK: Penelitian ini bertujuan untuk menguji pengaruh langsung peran audit internal terhadap efektivitas manajemen risiko dengan kompetensi account officer sebagai variabel intervening di BNI Syariah Cabang Surabaya. Metode yang digunakan adalah kuantitatif asosiatif dengan sampel jenuh 34 orang yang terdiri dari karyawan audit internal, account officer, unit pembiayaan dan manajemen risiko. Data dianalisis dengan menggunakan Partial Least Square (smartPLS 3.0). Hasil penelitian menunjukkan peran audit internal tidak berpengaruh secara langsung terhadap efektivitas manajemen risiko pembiayaan, audit internal berpengaruh positif terhadap kompetensi account officer, dan kompetensi account officer memediasi efektivitas manajemen risiko. Implikasi praktis, BNI Syariah Surabaya hendaknya tetap mempertahankan dan memperkuat peran audit internal dan kompetensi account officer untuk mengurangi risiko pembiayaan.
\end{abstract}

Kata Kunci: Risiko Pembiayaan, Manajemen Risiko, Audit Internal

ABSTRACT: This study aims to examine the role of internal audit as a function of supervision of the effectiveness of risk management with the competence of account officers as an intervening variable in BNI Syariah Surabaya Branch. The method used in this study is quantitative associative with a saturated sample of 34 people consisting of internal audit employees, account officers, financing units, and risk management. Data were analyzed using Partial Least Square (smartPLS 3.0). The results show that the role of internal audit is not directly influenced to the effectiveness of financial risk management, internal audit has a positive effect on the competency of account officers, and account officer becomes an intervening variable on the effectiveness of risk management. Practical implications, BNI Syariah Surabaya must maintain and strengthen the role of internal audit and account officers to reduce financing risks.

Keywords: Financing Risk, Risk Management, Internal Audit

\footnotetext{
*Surel Korespondensi Penulis: m.ahsan@uinsby.ac.id DOI: $10.24252 / \mathrm{minds} . v 6 i 1.7964$

ISSN-E: 2597-6990
} 


\section{PENDAHULUAN}

Lahirnya perbankan syariah merupakan respon aktif dari keinginan memiliki opsi lain sistem perbankan di Indonesia. Bank syariah dianggap memiliki sistem, manajemen dan produk yang lebih unggul dibanding bank konvensional. Anggapan tersebut bertolak belakang dengan fakta di lapangan. Data tahun 2017 menunjukkan bahwa nilai risiko pembiayaan (Non Performing Finance/NPF) bank syariah jauh lebih tinggi dibanding Non Performing Loan (NPL) bank konvensional, yaitu 4,77\% berbanding 2,59\% (OJK, 2017). Meskipun masih dalam batas normal di bawah $5 \%$ sesuai ketetapan OJK (Peraturan OJK No.29, 2014), akan tetapi hal ini memunculkan anggapan bahwa penerapan manajemen risiko pembiayaan bank syariah dianggap belum efektif.

Di antara bank umum syariah yang telah tumbuh dan berkembang di Indonesia, BNI Syariah tercatat memiliki rasio pembiayaan bermasalah yang baik, bahkan mampu bersaing dengan bank konvensional. Dalam empat tahun terakhir BNI Syariah mampu menekan rasio NPF di bawah 3\% (Laporan tahunan BNI Syrariah, 2014-2017) begitu pula dengan BNI Syariah Surabaya yang mampu menekan nilai NPF dibawah 4\% (Dwi, 20171). Hal tersebut menunjukkan bahwa penerapan manajemen risiko pembiayaan di BNI Syariah Cabang Surabaya dapat dikatakan telah berjalan efektif.

Fungsi pengawasan secara menyeluruh sebagai upaya pengendalian risiko pembiayaan atau untuk memperkecil NPF sangat dibutuhkan. Untuk menunjang hal tersebut, maka setiap perbankan membutuhkan tim audit internal yang berfungsi membantu petugas pembiayaan agar dapat melakukan tanggung jawabnya secara efektif. Jika terdapat temuan audit internal pembiayaan berisiko disebabkan lemahnya internal kontrol, maka hal tersebut dapat memengaruhi kinerja petugas pelaksana pembiayaan, termasuk juga account officer (Nugraheni dan Mustikawati, 2016).

Seorang account officer, dapat dikatakan sebagai pemain kunci sebuah bank dalam menyalurkan dana. Seorang account officer, tidak hanya mengejar target kuantitas pembiayaan tetapi juga harus memperhatikan kualitasnya. Kualitas accout officer dinilai dari kompetensi yang dimilikinya. Menurut Al-Makki (2010), kurangnya pembinaan dan pengawasan dari seorang account officer terhadap nasabah, dapat memicu pembiayaan bermasalah.

Penelitian ini ingin menguji ada atau tidaknya pengaruh secara langsung audit internal terhadap efektivitas manajemen risiko pembiayaan; audit internal terhadap kompetensi account officer dan kompetensi account officer sebagai variabel intervening terhadap efektivitas manajemen risiko pembiayaan di BNI Syariah Cabang Surabaya.

${ }^{1}$ Andry Dwi. 2017. Wawancara, tanggal, 5 Juni. 


\section{TINJAUAN TEORITIS}

\section{Audit Internal Bank}

Pengertian audit internal menurut IIA (Institute of Internal Auditor) yang dikutip dari Boynton, Johnson dan Kell (2001) adalah aktivitas independen, keyakinan objektif, dan konsultasi yang dirancang untuk menambah nilai dan meningkatkan operasi organisasi. Audit internal membantu organisasi untuk mencapai tujuannya dengan melakukan pendekatan sistematis dan disiplin untuk mengevaluasi dan meningkatkan efektivitas manajemen risiko, pengendalian dan proses tata kelola. Sedangkan menurut Sawyer, Dittenhofer, dan Scheiner (2006) audit internal adalah suatu penilaian yang objektif dan sistematis yang dilakukan oleh auditor terhadap operasi dan kontrol yang berbeda-beda untuk menentukan keakuratan informasi keuangan; identifikasi dan minimalisasi risiko yang dihadapi perusahaan; kepatuhan terhadap SOP (Standard Operational Procedure) yang berlaku dan pemanfaatan sumber daya yang efektif guna mencapai tujuan perusahaan.

Audit internal memiliki fungsi yang independen dalam organisasi untuk menguji dan mengevaluasi kegiatan yang dilaksanakan perusahaan (auditing). Audit internal memberikan saran kepada manajemen berdasarkan temuan-temuan yang ada di lapangan dengan tujuan untuk membantu semua bagian dalam perusahaan agar dapat melaksanakan fungsinya secara efektif dan efisien (Tugiman, 2006:11). Menurut Mulyadi (2014) audit internal yang bertugas menjalankan fungsi (auditing) pada risiko pembiayaan termasuk dalam audit kepatuhan; yaitu audit yang tujuannya untuk menentukan apakah yang diaudit sesuai dengan kondisi atau peraturan tertentu, dalam hal ini kesesuaian pembiayaan yang disalurkan dengan peraturan pembiayaan.

Sifat utama dari fungsi audit internal adalah independen yang dapat dipahami ke dalam dua pengertian yaitu pertama, mengambil sikap netral, tidak memihak dan bebas dari pengaruh serta keberpihakan pada kepentingan yang lebih besar/bernilai. Kedua, sifat independen ini merupakan kunci kebebasan serta batasan dalam menggali informasi seakurat mungkin sebagai aktivitas pokoknya dan menyajikannya dalam bentuk laporan hasil pengawasan (Kumaat, 2011).

Merujuk pada Ikatan Bankir Indonesia/IBI (2014), peran audit internal adalah sebagai pengendali risiko internal, khususnya dalam penyaluran pembiayaan. Rujukan IBI tersebut, didukung beberapa penelitian seperti, Khayati (2016) yang menyampaikan temuannya bahwa audit internal berperan dalam pengendalian risiko pembiayaan sebagai pemecah masalah, kepatuhan, negosiator dan pengendalian; Novatiani dan Fauzi (2014), menemukan audit internal berpengaruh terhadap pencegahan kredit macet; Damaputra (2013) menyampaikan temuannya bahwa audit internal memengaruhi kinerja dari account officer; Arista (2012) terdapat pengaruh dari peran auditor internal terhadap efektivitas pengelolaan enterprise risk management; Karagiorgo, 
Drogalas, Eleftheriadis dan Christodoulou (2010) menyatakan dalam hasil risetnya bahwa audit internal menjadi poin vital dalam efisiensi manajemen risiko sebagai konsekuensi dari kesuksesan dan kelangsungan sebuah bisnis.

Dalam penelitian ini, indikator-indikator dari variabel audit internal yang akan diuji merujuk pada ketentuan IBI diantaranya peran sebagai pemecah masalah, kepatuhan, negosiator, dan pengendalian.

\section{Kompetensi Account Officer}

Definisi kompetensi adalah kemampuan kerja setiap individu yang mencakup aspek pengetahuan, keterampilan, dan sikap kerja yang sesuai dengan standar yang ditetapkan (Undang-undang Republik Indonesia No. 13/ 2003, Tentang Ketenagakerjaan, Pasal 1; Sofo,1999)

Account officer adalah petugas yang melakukan pemasaran pembiayaan, kemudian melakukan analisis pembiayaan. Seorang account officer mengawalinya tugasnya dengan membuat perencanaan, usaha apa saja yang layak dibiayai dan berapa perkiraan dana yang diperlukan untuk menyalurkan pembiayaannya. Account officer kemudian melakukan kunjungan ke tempat nasabah, mewawancarainya, mengumpulkan informasi dan menganalisis apa yang diperlukan nasabah tersebut dan membuat suatu keputusan apakah permohonan pembiayaan yang diajukan debitur atau nasabah pantas dibiayai atau tidak (Tohir, 2012). Temuan Hasan (2015) menunjukkan kompetensi account officer berpengaruh terhadap kinerja pembiayaan, tetapi tidak berpengaruh terhadap risiko pembiayaan.

Dalam tugasnya, account officer memiliki fungsi ganda. Pertama, account officer merupakan marketing pembiayaan bank yang harus bekerja sesuai dengan peraturan yang telah ditetapkan, sehingga dapat memberikan hasil sesuai target yang ditetapkan. Kedua, account officer dituntut untuk memberikan kondisi yang paling baik kepada nasabahnya yang tercermin dari kemampuan nasabah dalam menyelesaikan pembiayaannnyahinggalunas serta mempromosikannya kepada nasabah lain. Bank yang memiliki account officer yang berkompeten tentu akan sangat membantu dalam menghadapi persaingan situasi perbankan saat ini. Pada dasarnya peran dari account officer menurut Jusuf (1997) adalah mengelola account, mengelola produk, mengelola kredit, mengelola penjualan, mengelola keuntungan dan risiko.

Kompetensi seorang account officer yang meliputi pengetahuan, keterampilan dan sikap merupakan manifestasi dari sumber daya manusia yang berkualitas. Aspek pengetahuan, menggambarkan seberapa luas wawasan keilmuan yang dimiliki seorang account officer perihal pembiayaan. Keterampilan menggambarkan kemampuan account officer dalam mengoptimalkan peluang pembiayaan yang ada, melakukan analisis, dan pengawasan nasabah. Sedangkan sikap, mencerminkan kepatuhan seorang account officer dalam melakukan pekerjaan sesuai prosedur, menerapkan prinsip kehati-hatian dan sesuai dengan syariah Islam.

Penelitian ini ingin menguji indikator-indikator yang telah tertuang dalam Undang-undang Republik Indonesia No. 13/ 2003, Tentang Ketenagakerjaan 
pada Pasal 1, dan yang disampaikan Sofo (1999). Indikator-indikator dari account officer tersebut diantaranya pengetahuan, keterampilan dan sikap dalam bekerja untuk mencegah terjadinya risiko pembiayaan.

\section{Efektivitas Manajemen Risiko}

Efektivitas dibentuk dari kata dasar efektif yang berarti ada pengaruh, berkhasiat atau suatu keadaaan yang memiliki dampak positif (Kamus Besar Bahasa Indonesia,2005). Efektivitas adalah pemanfaatan sumber daya, prasarana dan sarana dalam jumlah tertentu untuk menghasilkan sejumlah barang atau jasa dari aktivitas yang dijalankannya, sehingga menunjukkan tercapai atau tidaknya sasaran yang telah ditetapkan (Siagian,2001; Abdurahmat, 2003). Martoyo (2002) mendefiniskan efektivitas sebagai suatu kondisi atau keadaan dimana dalam memilih tujuan yang hendak dicapai dan sarana atau peralatan yang digunakan, harus disertai dengan kemampuan tiap-tiap individu sehingga tujuan yang diinginkan dapat dicapai dengan hasil yang memuaskan.

Konsep efektivitas pada dasarnya dibagi menjadi dua pendekatan, yaitu pendekatan tujuan dan pendekatan sistem. Pendekatan tujuan, untuk menentukan dan mengevaluasi efektivitas dari tujuan yang telah dicapai. Sedangkan pendekatan sistem, organisasi dipandang sebagai suatu unsur dari sejumlah unsur baik input maupun output yang saling berhubungan satu sama lain. Organisasi mengambil sumber (input) dari sistem yang lebih luas (lingkungan) kemudian mengolah sumber tersebut menjadi produk baru (output) (Donnelly, Gibson, dan Ivancevich, 1997).

Dari pengertian di atas, dapat dikatakan bahwa efektivitas adalah ukuran yang menyatakan seberapa jauh target telah tercapai baik secara kuantitas dan kualitas dari hasil usaha atas jasa kegiatan yang dijalankan berdasarkan kemampuan yang dimiliki oleh sumber daya manusia dan waktu yang ditetapkan, sehingga semakin tinggi target yang dicapai maka semakin tinggi pula tingkat efektivitasnya.

Efektif tidaknya manajemen risiko dapat dilihat dari tinggi rendahnya risiko gagal bayar dari debitur. Menurut Muhamad (2015) penyebab terjadinya risiko pembiayaan karena terlalu mudahnya bank memberikan pembiayaan karena kelebihan likuiditas sehingga penilaian pembiayaan kurang cermat dalam mengantisipasi berbagai kemungkinan risiko dari usaha yang dibiayai.

Karim (2010) menjelaskan bahwa risiko pembiayaan merupakan risiko yang disebabkan oleh adanya counterparty dalam memenuhi kewajibannya. Dalam bank syariah, risiko pembiayaan mencakup risiko terkait produk dan risiko terkait dengan pembiayaan korporasi. Sedangkan Ibrahim (2004) berpendapat bahwa pembiayaan bermasalah terjadi karena ketidakmampuan nasabah untuk memperoleh pendapatan yang cukup untuk melunasi pembiayaan yang telah disepakati. Faktor penyebabnya menurut Ismail (2010) karena faktor internal (analisis yang kurang tepat, adanya kolusi antar pejabat 
bank, keterbatasan pengetahuan pejabat bank terhadap jenis usaha debitur, campur tangan terlalu besar dari fihak terkait seperti komisaris dan direktur bank, dan kelemahan dalam pembinaan dan monitoring kredit debitur; faktor eksternal karena unsur kesengajaan seperti nasabah yang sengaja tidak membayar angsuran, debitur yang melakukan ekspansi usaha terlalu besar sehingga dana yang dibutuhkan besar dan penyelewengan yang dilakukan debitur; karena unsur ketidaksengajaan seperti perusahaan tidak mampu bersaing di pasar sehingga volume penjualan menurun, adanya perubahan kebijakan dan peraturan dari pemerintah dan bencana alam yang menyebabkan kerugian debitur).

Menurut Karim (2010) diperlukan kebijakan dalam mengeliminir pembiayaan bermasalah melalui manajemen risiko yang berfungsi sebagai peringatan dini (early warning system) terhadap kegiatan usaha bank. Anshori (2008) menawarkan prinsip pencegahan dengan menerapkan prinsip kehatihatian sebelum memberikan pembiayaan kepada nasabah dengan cara meneliti dan mengidentifikasi calon penerima pembiayaan. Identifikasi ini meliputi beberapa hal yang lazim disebut dengan analisis $5 \mathrm{C}$ dan $1 \mathrm{~S}$ dalam bank syariah, yaitu: Character, Capacity, Capital, Condition, Collateral dan Syariah. Untuk 5C tidak ada perbedaan yang mendasar dengan bank konvensional. Perbedaan pada perbankan syariah ada pada 1S (Ascarya,2011:4) yaitu dalam melakukan kegiatan bisnisnya, bank syariah selalu berlandaskan kepada prinsip keadilan, mencari keuntungan yang halal, menyalurka zakat, melarang monopoli dan bekerjasama untuk mencapai manfaat bagi masyarakat serta mengembangkan seluruh aspek kehalalan pada bisnis dan invesatsi yang tidak dilarang oleh syariat.

Berdasarkan ketentuan Bank Indonesia kolektibilitas dari suatu pembiayaan dapat dikelompokkan menjadi lima kategori yaitu lancar, dalam perhatian khusus, kurang lancar, diragukan dan macet (Peraturan Bank Indonesia No. 13/13/PBI/2011, Tentang Penilaian Kualitas Pembiayaan, Pasal 8.). Pembiayaan dikatakan bermasalah apabila sudah masuk dalam kategori tiga yaitu kurang lancar. Dalam proses menjadi bermasalah kemudian macet tentu didahului oleh tanda-tanda bahaya yang dapat diidentifikasi oleh bank syariah. Identifikasi tanda-tanda bahaya tersebut dapat dilakukan dengan memperhatikan aspek keuangan dan non keuangan. Untuk melakukan pencegahan tentu dibutuhkan pengawasan dan pembinaan nasabah agar tidak sampai terjadi gagal bayar.

Dari uraian di atas dapat disimpulkan bahwa efektivitas manejemen risiko pembiayaan adalah kemampuan bank dalam mengelola sumber daya yang ada dalam rangka mencegah dan mengendalikan risiko gagal bayar nasabah yang disebabkan oleh faktor-faktor tertentu. Hasibuan (2006) berpendapat, bank dinilai efektif atau tidak dilihat dari bagaimana bank tersebut menghadapi risiko-risiko pembiayaan yang mungkin timbul, di antaranya analisis pembiayaan melalui prinsip $5 \mathrm{C}$ dan $1 \mathrm{~S}$, monitoring proyekproyek yang dibiayai, penilaian dan peninjauan agunan, penyelesaian 
pembiayaan bermasalah dan penetapan limit untuk seluruh eksposure kepada setiap individu.

Penelitian ini ingin menguji indikator-indikator efektivitas manajemen risiko yang telah disampaikan Hasibuan (2006). Indikator-indikator tersebut adalah analisis pembiayaan, monitoring proyek-proyek yang dibiayai, penilaian dan peninjauan agunan, penyelesaian pembiayaan bermasalah dan penetapan limit yang diberikan kepada debitur untuk menghindari risiko pembiayaan.

Dari kajian teori dan riset terdahulu yang telah dipaparkan, maka penelitian ini ingin menguji pengaruh dari audit internal $\left(X_{1}\right)$ terhadap efektivitas manajemen risiko pembiayaan $(\mathrm{Y})$; pengaruh audit internal $\left(\mathrm{X}_{1}\right)$ terhadap kompetensi account officer $\left(X_{2}\right)$, pengaruh kompetensi account officer $\left(X_{2}\right)$ terhadap efektivitas manajemen risiko pembiayaan $(\mathrm{Y})$ dan pengaruh audit internal $\left(X_{1}\right)$ terhadap efektivitas manajemen risiko pembiayaan $(Y)$ dengan kompetensi account officer $\left(\mathrm{X}_{2}\right)$ sebagai intervening. Hipotesis dan kerangka konseptual penelitian diajukan sebagai berikut:

$\mathrm{H}_{1}$ : Terdapat pengaruh positif secara langsung dari audit internal $\left(\mathrm{X}_{1}\right)$ terhadap efektivitas manajemen risiko pembiayaan $(\mathrm{Y})$ di BNI Syariah Cabang Surabaya

$\mathrm{H}_{2}$ : Terdapat pengaruh positif secara langsung dari audit internal $\left(\mathrm{X}_{1}\right)$ terhadap kompetensi account officer $\left(\mathrm{X}_{2}\right)$ di BNI Syariah Cabang Surabaya

$\mathrm{H}_{3}$ : Terdapat pengaruh positif secara langsung dari Kompetensi Account officer $\left(\mathrm{X}_{2}\right)$ terhadap Efektivitas Manajemen Risiko Pembiayaan (Y) di BNI Syariah Cabang Surabaya

$\mathrm{H}_{4}$ : Terdapat pengaruh audit internal $\left(X_{1}\right)$ terhadap efektivitas manajemen risiko pembiayaan $(\mathrm{Y})$ dengan kompetensi account officer $\left(\mathrm{X}_{2}\right)$ sebagai variabel intervening.

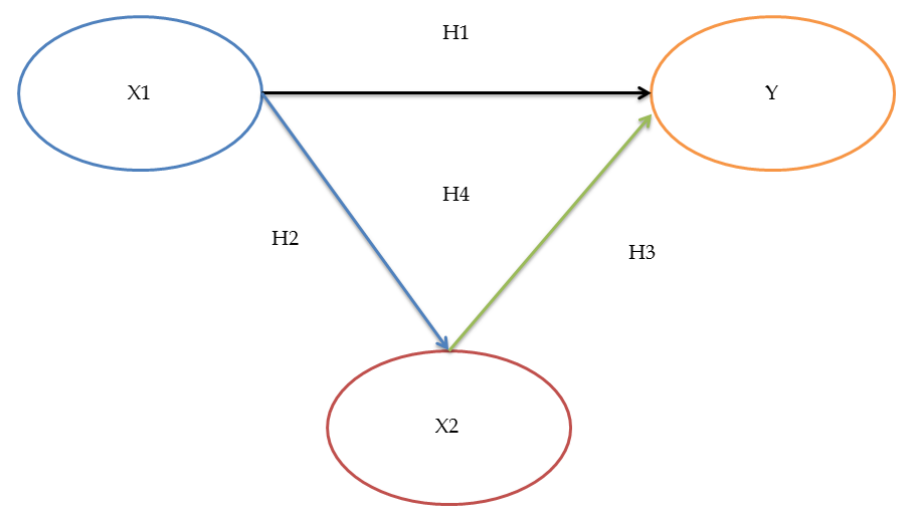

Gambar 1. Kerangka Konseptual Penelitian

\section{METODE PENELITIAN}

Penelitian ini termasuk penelitian kausal, yang ingin melihat hubungan sebab akibat antara variabel bebas dan terikat (Suryabrata, 2005). Pendekatan kuantitatif digunakan untuk menjawab tujuan penelitian (Hadi, 1994:202). Populasi penelitian ini adalah seluruh karyawan bagian audit internal, account 
officer, petugas unit pembiayaan dan manajemen risiko pada kantor cabang BNI Syariah di Surabaya. Teknik pengambilan sampel menggunakan sampel jenuh (Sugiyono, 2008). Data penelitian dikumpulkan dengan menyebar kuesioner kepada 34 responden dan selanjutnya data dianalisis dengan menggunakan Partial Least Square (smartPLS 3.0).

\section{HASIL}

Evaluasi Outer Model

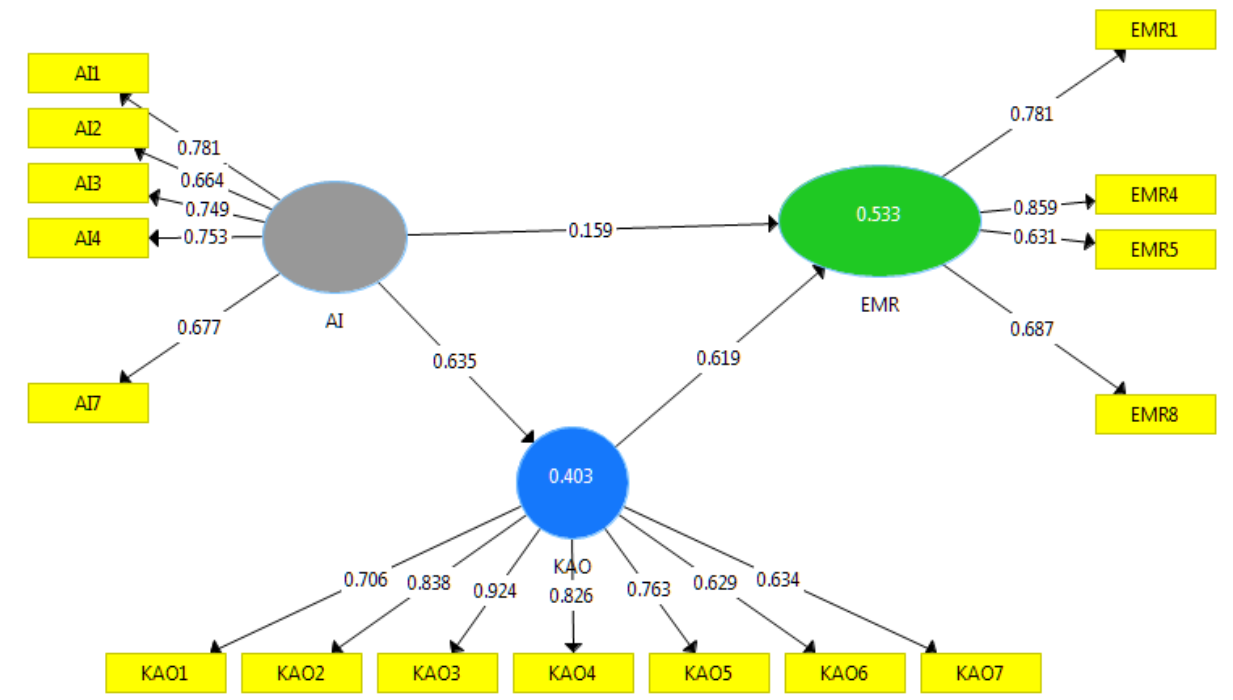

Gambar 2. Outer Model

Indicator reliability digunakan untuk mengukur reliabilitas indikator dengan melihat loading factor. Syarat yang digunakan untuk memenuhi kriteria layak bila nilai loading factor $>0,7$ akan tetapi sampai 0,6 masih diizinkan (Latan dan Ghozali, 2017:87; Husein, 2016:9). Nilai loading factor masing-masing indikator penelitian ini setelah membuang loading factor yang tidak memenuhi syarat dapat dilihat pada Tabel 1. berikut: 


\begin{tabular}{|c|c|c|c|c|c|}
\hline variabel & Indikator & $\begin{array}{l}\text { Outer } \\
\text { loading }\end{array}$ & variabel & Indikator & $\begin{array}{c}\text { Outer } \\
\text { loading }\end{array}$ \\
\hline \multirow{5}{*}{$\begin{array}{c}\text { Audit } \\
\text { Internal } \\
(\mathrm{AI})\end{array}$} & AI1 & 0,781 & \multirow{2}{*}{$\begin{array}{c}\text { Efektivitas } \\
\text { Manajemen } \\
\text { Risiko } \\
\text { Pembiayaan } \\
\text { (EMR) }\end{array}$} & EMR1 & 0,781 \\
\hline & AI2 & 0,664 & & EMR4 & 0,859 \\
\hline & AI3 & 0,749 & & EMR5 & 0,631 \\
\hline & AI4 & 0,753 & & EMR8 & 0,687 \\
\hline & AI7 & 0,677 & & & \\
\hline \multirow{7}{*}{$\begin{array}{c}\text { Kompetensi } \\
\text { Account } \\
\text { officer } \\
\text { (KAO) }\end{array}$} & KAO1 & 0,706 & & & \\
\hline & $\mathrm{KAO} 2$ & 0,838 & & & \\
\hline & KAO3 & 0,924 & & & \\
\hline & KAO4 & 0,826 & & & \\
\hline & KAO5 & 0,763 & & & \\
\hline & KAO6 & 0,629 & & & \\
\hline & KAO7 & 0,634 & & & \\
\hline
\end{tabular}

Tabel 1. Nilai outer loading

Composite Reliability (CR), digunakan untuk melihat reliabilitas konstruk yang nilai composite reliabilitynya harus > 0,7 (Ghozali, 2014:43; Latan dan Ghozali, 2017:87-88). Cara lain juga dapat melihat nilai cronbach alpha (CA). Jika nilai CA > 0,7 (Eisingerich dan Rubera, 2010:27) maka dapat dikatakan reliabel. Berikut tabel nilai CR dan CA.

\begin{tabular}{|c|c|c|}
\hline Variabel & CR & CA \\
\hline Audit Internal (AI) & 0,848 & 0,776 \\
\hline Kompetensi Account officer (KAO) & 0,907 & 0,880 \\
\hline $\begin{array}{c}\text { Efektivitas Manajemen Risiko } \\
\text { Pembiayaan (EMR) }\end{array}$ & 0,831 & 0,727 \\
\hline
\end{tabular}

\section{Tabel 2. Nilai CR dan CA}

Discriminant validity digunakan untuk melihat validitas tiap-tiap indikator penelitian yang telah menyusun variabelnya masing-masing. Nilai cross loading digunakan untuk mengukurnya. Suatu indikator dinyatakan memenuhi discriminant validity bila nilai cross loading indikator pada variabelnya memiliki nilai terbesar dibanding variabel lain yang diobservasi (Ghozali, 2014: 39-40). Berikut tabel discriminant validitynya.

\begin{tabular}{|c|c|c|c|}
\hline & EMR & AI & KAO \\
\hline EMR & $\mathbf{0 , 7 4 5}$ & & \\
\hline AI & 0,552 & $\mathbf{0 , 7 2 6}$ & \\
\hline KAO & 0,720 & 0,636 & $\mathbf{0 , 7 6 7}$ \\
\hline
\end{tabular}

Tabel 3. Nilai Discriminant Validity 
Discrimant validity juga bisa dilihat melalui nilai average variant extracted (AVE). Untuk model yang baik nilainya harus > 0,5 (Ghozali,2014:40). Nilai AVE varibel dalam penelitian ini nilainya dapat dilihat pada tabel berikut:

\begin{tabular}{|c|c|}
\hline Variabel & AVE \\
\hline Audit Internal & 0,528 \\
\hline Kompetensi Account officer & 0,588 \\
\hline $\begin{array}{c}\text { Efektivitas Manajemen } \\
\text { Risiko Pembiayaan }\end{array}$ & 0,555 \\
\hline
\end{tabular}

Tabel 4. Nilai Average Variant Extracted

Berdasarkan sajian data dalam Tabel 4. di atas, diketahui bahwa nilai AVE variabel audit internal, kompetensi account officer dan efektivitas manajemen risiko pembiayaan $>0,5$. Artinya bahwa setiap variabel telah memiliki discriminant validity yang baik.

\section{Evaluasi Inner Model}

Evaluasi inner model dijelaskan melalui hasil uji path, goodness of fit dan hipotesis.

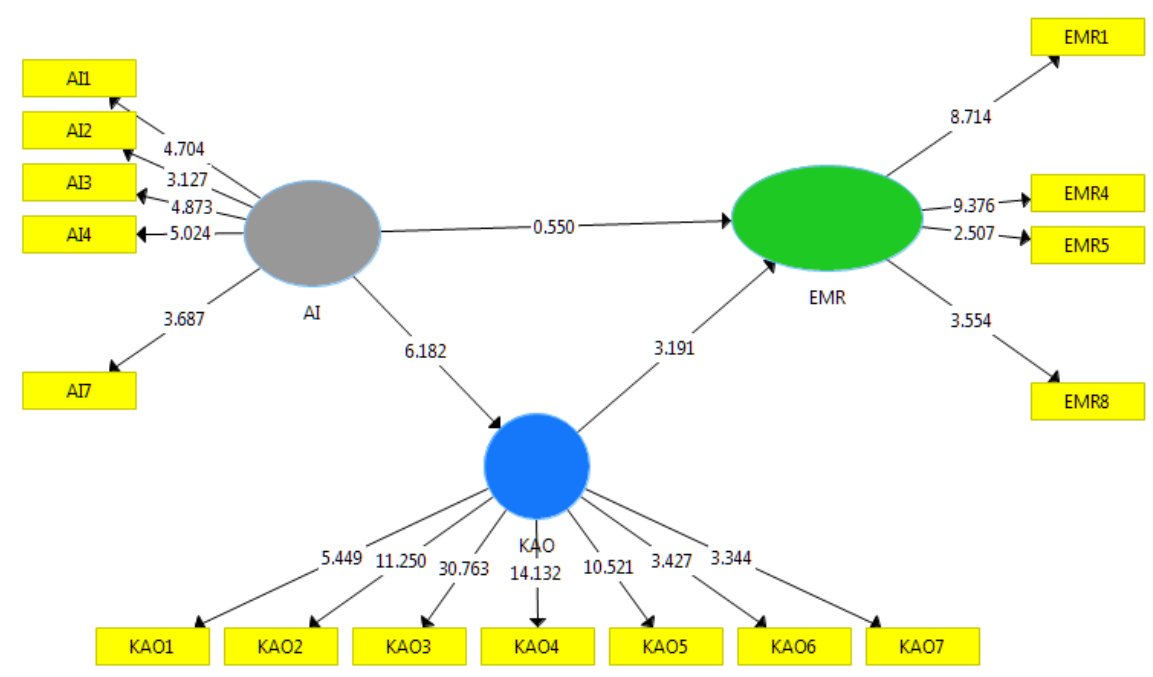

Gambar 3. Inner Model

Path coefficient digunakan untuk menunjukkan seberapa kuat pengaruh variabel eksogen terhadap variabel endogen. Sedangkan coefficient determination (R-Square) digunakan untuk mengukur seberapa besar variabel endogen dipengaruhi oleh variabel lainnya. Chin menyebutkan hasil $R$-square sebesar 0,67 ke atas untuk variabel laten endogen dalam model struktural mengindikasikan variabilitas variabel eksogen terhadap variabel endogen termasuk dalam kategori baik. Sedangkan jika hasilnya sebesar 0,33-0,67 maka termasuk dalam kategori sedang, dan jika hasilnya sebesar 0,19 - 0,33 maka termasuk dalam kategori lemah (Ghozali, 2014:42). 
Dari skema inner model yang telah ditampilkan pada Gambar 3. di atas dapat dijelaskan bahwa nilai t-statistik terbesar ditunjukkan oleh pengaruh audit internal terhadap kompetensi account officer sebesar 6,182. Pengaruh terbesar kedua adalah kompetensi account officer terhadap efektivitas manajemen risiko pembiayaan sebesar 3,191 dan pengaruh yang paling kecil ditunjukkan oleh pengaruh audit internal terhadap efektivitas manajemen risiko pembiayaan sebesar 0,550 . Hal tersebut menunjukkan jika semakin besar nilai path coefficient satu variabel eksogen terhadap variabel endogen, maka semakin kuat pula pengaruh variabel eksogen terhadap variabel endogen tersebut.

\section{Uji Kebaikan Model}

Dari hasil pengolahan data diperoleh nilai $R$-Square sebagai berikut:

\begin{tabular}{|c|c|}
\hline Variabel & Nilai $R$-Square \\
\hline Kompetensi Account officer & 0,403 \\
\hline $\begin{array}{c}\text { Efektivitas Manajemen } \\
\text { Risiko Pembiayaan }\end{array}$ & 0,533 \\
\hline
\end{tabular}

Tabel 5. Nilai R-square

Berdasarkan data pada Tabel 5. di atas, diketahui bahwa nilai $R$-Square untuk variabel kompetensi account officer sebesar 0,403. Artinya presentase besarnya kompetensi account officer dapat dijelaskan oleh audit internal sebesar 40,3\% sedangkan efektivitas manajemen risiko pembiayaan dapat dijelaskan oleh audit internal dan kompetensi account officer sebesar 53,3\%.

Penilaian goodness of fit diperoleh dari nilai $Q$-Square predictive relevance (Latan dan Ghozali, 2017:93; Solimun, 2010:197). Semakin tinggi nilai $Q$-Square, maka model semakin baik. Hasil perhitungan nilai $Q$-Square sebagai berikut:

$$
\begin{array}{ll}
\text { Q-Square } & =1-\left[\left(1-\mathrm{R}^{2} 1\right) \times\left(1-\mathrm{R}^{2} 2\right)\right] \\
& =1-[(1-0,403) \times(1-0,533)] \\
& =1-(0,597 \times 0,467) \\
& =1-0,279 \\
& =0,721
\end{array}
$$

Dari hasil perhitungan, nilai $Q$-Square sebesar 0,721, artinya model mampu menjelaskan efektivitas manajemen risiko dalam penelitian ini sebesar $72,1 \%$. Sedangkan sisanya sebesar 27,9\% dijelaskan oleh faktor lain yang berada di luar model penelitian. Dengan demikian, dari hasil tersebut maka model penelitian ini dapat dinyatakan telah memiliki goodness of fit yang baik.

\section{Uji Hipotesis}

Uji hipotesis dilakukan dengan melihat nilai t-Statistics dan nilai $P$ Values. Hipotesis penelitian dapat dinyatakan diterima apabila nilai $P$-Values < 
0,05 (Yamin dan Kurniawan, 2011:54). Berikut ini adalah hasil uji hipotesis yang diperoleh dalam penelitian ini melalui:

\begin{tabular}{|c|c|c|c|c|}
\hline Hipotesis & Pengaruh & t-statistics & P-Values & Hasil \\
\hline $\mathrm{H}_{1}$ & $\begin{array}{c}\text { Audit Internal => } \\
\text { Efektivitas } \\
\text { Manajemen Risiko } \\
\text { Pembiayaan }\end{array}$ & 0,550 & 0,583 & Ditolak \\
\hline $\mathrm{H}_{2}$ & $\begin{array}{c}\text { Audit Internal } \\
=>\text { Kompetensi } \\
\text { Account officer }\end{array}$ & 6,182 & 0,000 & Diterima \\
\hline $\mathrm{H}_{3}$ & $\begin{array}{c}\text { Kompetensi } \\
\text { Account officer }=> \\
\text { Efektivitas } \\
\text { Manajemen Risiko } \\
\text { Pembiayaan }\end{array}$ & 3,191 & 0,002 & Diterima \\
\hline
\end{tabular}

Tabel 6. t-statistics dan P-values

Dari Tabel 6. di atas, dapat diketahui bahwa tiga hipotesis yang diajukan pada penelitian ini tidak semuanya diterima. Hipotesis pertama ditolak karena p-values lebih $>0,05$.

Pengujian $\mathrm{H}_{4}$ dilakukan melalui nilai path coeficient yang dapat dilihat dari tabel berikut:

\begin{tabular}{|l|c|c|}
\hline $\begin{array}{l}\text { Audit Internal => } \\
\text { Efektivitas } \\
\text { Manajemen Risiko } \\
\text { Pembiayaan }\end{array}$ & $\begin{array}{c}\text { Original } \\
\text { Sample (O) }\end{array}$ & Perhitungan \\
\hline $\begin{array}{l}\text { Audit Internal => } \\
\text { Kompetensi Account } \\
\text { Officer }\end{array}$ & 0,159 & 0,159 \\
\hline $\begin{array}{l}\text { Kompetensi Account } \\
\text { Officer => Efektivitas } \\
\text { Manajemen Risiko } \\
\text { Pembiayaan }\end{array}$ & 0,619 & $0,635 \times 0,619=0,393$ \\
\hline
\end{tabular}

Tabel 7. Path coeficient pengujian $\mathrm{H}_{4}$

Dari perhitungan dapat dilihat bahwa 0,159<0,393 artinya variabel kompetensi account officer merupakan variabel intervening dari audit internal terhadap efektivitas manajemen risiko pembiayaan. 


\section{PEMBAHASAN}

\section{Pengaruh Audit Internal terhadap Efektivitas Manajemen Risiko Pembiayaan}

Dari hasil uji hipotesis, pengaruh audit internal tidak berpengaruh secara langsung terhadap efektivitas manajemen risiko pembiayaan. Hal tersebut mendukung pendapat Sawyer, Dittenhofer dan Scheiner $(2006 ; 7)$ bahwa sasaran utama tugas dari audit internal adalah membantu dewan komisaris dan pihak manajemen dalam melaksanakan tanggung jawabnya secara efektif.

Fakta yang ditemukan di BNI Syariah Cabang Surabaya mendukung hasil uji hipotesis. Dari wawancara dengan Dwi dan Najib² (2017), audit internal berperan secara tidak langsung dalam menunjang efektivitas manajemen risiko pembiayaan dalam beberapa hal di antaranya audit internal selalu memeriksa kebenaran dokumen dan laporan keuangan usaha nasabah, menilai kekuatan hukum agunan yang dijaminkan nasabah, menilai ketaataan petugas pembiayaan dalam menyalurkan dana agar jangan sampai terjadi kasus-kasus seperti overfinancing, side streaming dan lain sebagainya.

Hasil uji path coefficient menunjukkan bahwa pengaruh audit internal terhadap efektivitas manajemen risiko memiliki nilai t-statistik terkecil ( $t$-Statistics sebesar 0,550). Hal tersebut karena audit internal tidak berperan secara langsung dalam proses pembiayaan, melainkan setelah realisasi terjadi. Temuan-temuan terkait pembiayaan yang tidak sesuai prosedur dan upaya untuk mitigasi risiko baru dapat dilakukan setelah dievaluasi agar tidak terjadi lagi pada pembiayaan-pembiayaan selanjutnya.

Meskipun peran audit tidak dirasakan pada saat proses pembiayaan, namun melalui hasil audit berdasarkan fakta-fakta yang ditemukan secara tidak langsung, audit internal membantu tim manajemen risiko dalam meminimalisir risiko pembiayaan dan meningkatkan kualitas pembiayaan. Peran audit internal dalam proses meminimalisisr resiko di BNI Syariah Cabang Surabaya diantaranya memeriksa kebenaran dokumen dan laporan keuangan nasabah, menilai kekuatan hukum agunan yang dijaminkan nasabah dan menilai ketaatan petugas pembiayaan dalam menyalurkan dana agar tidak terjadi over financing, side streaming dan lain-lain.

Penolakan $\mathrm{H}_{1}$ dalam penelitian ini bukan berarti bahwa peran dari audit internal tidak mendukung efektivitas dalam meminimalisir risiko pembiayaan. Peran audit internal tetap ada tetapi tidak secara langsung. Hasil penelitian ini bertolak belakang dengan hasil penelitian yang dilakukan oleh Novatiani dan Fauzi (2014) yang menyatakan bahwa audit internal berpengaruh secara langsung terhadap pencegahan kredit macet; Nainggolan (2013) yang menyatakan bahwa keterlibatan audit internal dalam Enterprise Risk Management (ERM) berpengaruh negatif terhadap pelaporan kerusakan prosedur risiko

\footnotetext{
${ }^{2}$ Andry Dwi dan Najib. 2017. Wawancara, tanggal 5 Juni.
} 
perusahaan. Hal tersebut dikarenakan audit internal pada objek yang diteliti kurang terlibat dalam proses manajemen risiko. Selain itu, pengaruh hubungan audit internal dengan komite audit yang kuat menyebabkan pelaporan kerusakan prosedur risiko menjadi tidak objektif. Temuan Nainggolan tersebut berbeda dengan kondisi di BNI Syariah Cabang Surabaya, tim audit internal memiliki tingkat independensi yang tinggi, tidak terpengaruh oleh dekat atau tidaknya hubungan antar divisi atau antar komite audit sendiri. Jika terdapat temuan yang tidak sesuai dengan prosedur maka akan menjadi laporan hasil audit.

\section{Pengaruh Audit Internal terhadap Kompetensi Account officer}

Hasil uji path coefficient menunjukkan bahwa pengaruh audit internal terhadap kompetensi account officer memiliki tingkat signifikansi terkuat dari tiga hipotesis yang diujikan (t-statistic sebesar 6,182). Temuan penelitian ini sesuai dengan pendapat Sawyer, Dittenhofer dan Scheiner (2006) tentang peran audit internal, yaitu menjamin kepatuhan petugas pembiayaan agar selalu bertugas sesuai prosedur dan menghindari segala bentuk penyimpangan dalam proses pembiayaan. Pendapat Sawyer, Dittenhofer dan Scheiner (2006) di atas, sesuai dengan fakta (Dwi dan Najib33 2017) bahwa di BNI Syariah Cabang Surabaya jarang sekali terjadi kesalahan-kesalahan yang dilakukan account officer. Kasus yang pernah terjadi adalah pembiayaan over financing, dimana pembiayaan tersebut tidak sesuai dengan Re-Payment Capacity nasabah yang kemudian menjadi pembiayaan bermasalah. Dari temuan audit internal tersebut kemudian dievaluasi agar tidak terulang kembali pada pembiayaan selanjutnya.

Hasil uji hipotesis menunjukkan bahwa terdapat pengaruh positif dan signifikan dari audit internal terhadap kompetensi account officer. Hasil tersebut mendukung penelitian yang dilakukan oleh Damaputra (2013) yang menyimpulkan terdapat pengaruh dari audit internal dalam menunjang kinerja account officer PT. Bank Mega (Persero) Tbk. Bandung.

Pengaruh Kompetensi Account officer terhadap Efektivitas Manajemen Risiko Pembiayaan

Hasil uji hipotesis menunjukkan terdapat pengaruh positif dan signifikan dari variabel kompetensi account officer terhadap efektivitas manajemen risiko pembiayaan. Artinya, semakin berkompeten account officer yang dimiliki BNI Syariah Cabang Surabaya, semakin menunjang penerapan manajemen risiko pembiayaann yang efektif. Hasil uji hipotesis tersebut, telah memperkuat hasil penelitian yang dilakukan oleh Hasan (2015) bahwa kompetensi account officer berpengaruh signifikan terhadap kinerja pembiayaan. Variabel kinerja pembiayaan yang ditelitinya memiliki

\footnotetext{
${ }^{3}$ Andry Dwi dan Najib. 2017. Wawancara, tanggal 5 Juni.
} 
kesamaan dengan efektivitas manajemen risiko pembiayaan dari beberapa indikator yang digunakan. Di antaranya yaitu account officer harus memperhatikan prosedur dalam menjalankan tugasnya selaku marketing pembiayaan dan memperhatikan kuantitas dan kualitas pembiayaan secara seimbang.

Menurut Arifin (2010), keahlian account officer dalam menganalisis karakter nasabah dan melakukan investigasi terhadap usaha nasabah sangatlah dibutuhkan agar kebutuhan pembiayaan yang diberikan sesuai dengan keperluan nasabah. Selain itu account officer juga berperan sebagai konsultan dalam memandu nasabah untuk membuat neraca perkiraan usaha nasabah serta kemampuan cash flow membayarnya. Semua kemampuan tersebut harus dimiliki seorang account officer sebelum proposal pengajuan pembiayaan disetujui atau tidak oleh komite pembiayaan. Tahapan-tahapan tersebut harus dilakukan sesuai prosedur sebagai bentuk penerapan manajemen risiko dan meminimalisir terjadinya risiko.

Di BNI Syariah Cabang Surabaya, prinsip kehati-hatian wajib diterapkan bagi setiap account officer ketika berinteraksi dengan nasabah. Menurut Yossi ${ }^{4}$ (2017) salah satu account officer BNI Syariah Cabang Surabaya, di antara penerapan prinsip analisis $5 C+1 S$, yang paling menentukan lancar atau tidaknya pembiayaan adalah karakter nasabah (character). Sebab, walaupun seorang nasabah pembiayaan memiliki kemampuan secara materi untuk mengembalikan angsuran, tetapi jika karakternya sulit untuk mengeluarkan uang, maka bisa jadi masalah. Tugas utama seorang account officer di BNI Syariah Cabang Surabaya adalah mencari nasabah pembiayaan, melakukan identifikasi terhadap karakter dan usaha nasabah, memandu dari proses awal hingga pencairan, melakukan pengawasan dan pembinaan sampai pembayaran lunas serta menjalin hubungan kemitraan (customer relationship). Tidak hanya itu, ketika usaha nasabah sedang dalam kondisi kurang menguntungkan yang menyebabkan pembiayaan bermasalah, account officer juga harus membantu melakukan restructuring (menambah jangka waktu pelunasan atau menurunkan nilai angsuran). Menurut Syakir (2014), kelebihan account officer dalam membangun customer relationship dapat memberikan keuntungan bagi bank melalui promosi yang dilakukan nasabah yang sudah merasakan layanan account officer kepada nasabah yang lain.

Berdasarkan hasil uji hipotesis di atas dapat disimpulkan bahwa penerapan manajemen risiko yang efektif harus didukung oleh kompetensi account officer. Temuan Al-Makki (2010) menyampaikan bahwa pembiayaan bermasalah dapat terjadi karena account officer lemah dalam melakukan pengawasan dan pembinaan, kurang pengalaman atau kurang memahami tentang pembiayaan bermasalah dan penanganannya.

${ }^{4}$ Hadi Yossi.2017. Wawancara, tangaal 12 Juni. 


\section{Pembuktian Intervening Variable}

Dari hasil perhitungan path coeficient pada Tabel 7, nilai koefisien audit internal lebih kecil dibanding nilai perkalian dari path coeficient antara audit internal ke kompetensi account officer dan dari kompetensi account officer ke efektivitas manajemen risiko pembiayaan $(0,159<0,393)$. Hal tersebut menandakan bahwa peran dari audit internal dalam menekan angka pembiayaan macet tidak dirasakan secara langsung, tetapi melalui kompetensi account officer. Peran kompetensi account officer sangat diperlukan dan sebagai garda terdepan dalam menekan angka pembiayaan macet. Peran audit internal bukan berarti tidak dibutuhkan, tetapi peran kompetensi account officer sebagai pemindai awal dalam proses pembiayaan terhadap nasabah harus lebih dioptimalkan untuk memperkecil angka pembiayaan macet di BNI Syariah Cabang Surabaya.

\section{PENELITIAN LANJUTAN}

Penelitian ini memiliki keterbatasan antara lain adalah dalam teknik pengumpulan data, hanya menggunakan kuesioner sebagai sumber utama, sehingga data yang diperoleh masih bersifat subjektif karena hanya menilai dari persepsi karyawan. Sedangkan teknik wawancara yang digunakan belum komprehensif dan hanya sebagai pelengkap semata; variabel yang diobservasi hanya audit internal dan kompetensi account officer untuk melihat pengaruhnya terhadap efektivitas manajemen risiko pembiayaan. Maka bagi penelitian lanjutan keterbatasan-keterbatasan tersebut dapat dilengkapi dengan kombinasi teknik pengumpulan data yang lebih komprehensif dan menambah variabel observasi terkait efektivitas manajemen risiko dalam meminimalisir pembiayaan bermasalah seperti pertumbuhan ekonomi, laju inflasi dan lainnya.

\section{DAFTAR PUSTAKA}

Abdurahmat. 2003. Pengertian Efektivitas. Jakarta: PT. Rineka Cipta.

Anshori, Abdul Ghofur. 2008. Penerapan Prinsip Syariah Dalam Lembaga Keuangan;

Lembaga Pembiayaan; dan Perusahaan Pembiayaan.Yogyakarta: Pustaka Pelajar.

Arifin, Zainul. 2010. Dasar-dasar Manajemen Bank Syariah. Bandung: Alfabet.

Arista, Vicky. 2012. Pengaruh Peran Auditor Internal terhadap Efektivitas Pengelolaan Enterpise Risk Management: Studi Kasus pada PT. Bank X di Bandung. TesisUniversitas Kristen Maranatha, Bandung.

Ascarya. 2011. Akad dan Produk Bank Syariah. Jakarta: Rajawali Press.

Boynton, William C., Johnson, Raymond N., Kell, Walter G. 2001. Modern Auditing. New York: John Willey \& Sons Inc. 
Damaputra, Rangga. 2013. Pengaruh Audit Internal terhadap Kinerja Account Officer - Studi Kasus pada PT. Bank Mega (Persero) Tbk. Bandung. Skripsi-Universitas Widyatama, Bandung.

Departemen Pendidikan Nasional.2005. Kamus Besar Bahasa Indonesia . Jakarta: Balai Pustaka.

Donnelly, James H, Gibson, James L., Ivancevich, John M. 1997. Management. Praha:Grada Publishing.

Eisingerich, Andreas B. dan Gaia Rubera. 2010. Drivers of Brand Commitment: A Cross National Investigation". Journal of International Marketing. Vol. 18 No. 2, pp. 64-79.

Ghozali, Imam. 2014. Structural Equation Modeling - Metode Alternatif dengan Partial Least Squares (PLS). Semarang: Universitas Diponegoro.

Hadi, Sutrisno. 1994. Metodologi Research. Yogyakarta: Andi Offset.

Hasan, Brian Ahmad Nur. 2015. Pengaruh Komptensi Account Officer dan Informasi Asimetri terhadap Kinerja Pembiayaan Murabahah dengan Risiko Pembiayaan Murabahah sebagai Variabel Intervening pada BMT di Kabupaten Banyuwangi dan Jember. Skripsi--Universitas Jember.

Hasibuan Malayu S. P. 2006. Dasar-dasar Perbankan. Jakarta: Bumi Aksara.

Husein, Ananda Sabil.2016. Variance Based SEM dengan smartPLS 3.0 (materi workshop). Malang: Universitas Brawijaya

Ibrahim, Johannes. 2004. Cross Defeult dan Collateral Sebagai Upaya Dalam Penyelesaian Kredit Bermasalah. Bandung: PT. Refika Aditama.

Ikatan Bankir Indonesia. 2014. Mengelola Bank Syariah. Jakarta: PT. Gramedia Pustaka.

Ismail. 2010. Manajemen Perbankan dari Teori Menuju Aplikasi. Jakarta: Kencana.

Jusuf, Jopie. 1997. Panduan Dasar untuk Account Officer. Yogyakarta: YKPN.

Karagiorgo, T. Drogala, G. Eleftheriadis, I. Christodoulou, P. 2010. Internal Audit Contribution to Efficient Risk Management, Journal of Business Management, Vol. 2 No. 1, pp. 15-23.

Karim, Adiwarman A. 2010. Bank Islam Analisis Fiqih dan Keuangan. Jakarta: PT.Raja Grafindo Persada.

Khayati, Ismatul. 2015. Peran Audit Internal dalam Pengendalian Risiko Pembiayaan di Bank BRI Syariah Kantor Cabang Diponegoro Surabaya. Akuntansi Integratif. Vol. 1 No. 1., 15-46.

Kumaat, Valery G. 2011. Internal Audit. Jakarta: Erlangga.

Laporan Otoritas Jasa Keuangan Triwulan IV 2017

Laporan Tahunan BNI Syariah, 2014-2017

Latan, Hengky dan Ghozali, Imam. 2017. Partial Least Square, Konsep Metode dan Aplikasi Menggunakan WrapPLS5.0, Third edition. Semarang: Badan PenerbitUndip.

Makki, H. M. Arsyad. 2010. Pengawasan dan Pembinaan Pembiayaan Bermasalah oleh Account Officer - Studi di PT. BPR Syariah Baktimakmur Indah Krian Sidoarjo. Tesis--UIN Sunan Kalijaga. 
Martoyo, Susilo. 2002. Sumber Daya Manusia dan Produktivitas Kerja. Bandung:Bina Aksara.

Muhamad. 2015. Manajemen Dana Bank Syariah. Jakarta: PT. Raja Grafindo Persada.

Mulyadi. 2014. Auditing. Jakarta: Salemba Empat.

Nainggolan, Yosua Hasudungan. 2013. Pengaruh Keterlibatan Auditor Internal dalam Manajemen Risiko Perusahaan. Skripsi-Universitas Diponegoro, Semarang.

Novatiani, R. Ait dan Muhammad Fauzi. 2014. Pengaruh Audit Internal terhadap Pencegahan Kredit Macet". Prosiding: Seminar Nasional dan Call for Papers Sustainable Competitive Advantage 4.

Nugraheni, Brifana Satriawati dan Rr. Indah Mustikawati. 2016. Peran Audit Internal sebagai Alat Bantu Manajemen untuk Menunjang Keefektivan Pengendalian Internal Pemberian Kredit pada PT. BRI (Persero) Tbk.Kantor Cabang Wates. Profita, Edisi 5.

Peraturan Bank Indonesia No. 13/13/PBI/2011, Tentang Penilaian Kualitas Pembiayaan.

Peraturan Otoritas Jasa Keuangan No.29/ POJK.05/ 2014 Tentang Penyelenggaraan Usaha Pembiayaan.

Sawyer, Lawrence B., Dittenhofer, Mortimer A., Scheiner, James H. 2006. Sawyer's Internal Auditing, (Ter. Ali Akbar). Jakarta: Salemba Empat.

Siagian, Sondang P. 2001. Manjamen Sumber Daya Manusia. Jakarta: Bumi Aksara.

Sofo, Francesco. 1999. Human Resources Development. Australia: Wariewood \& Professional Publishing Pty Limited.

Solimun, 2010. Analisis Multivariat Pemodelan Struktural, Metode Partial Least Square-PLS. Malang: Citra Malang.

Sugiyono. 2008. Metode Penelitian Kuantitatif, Kualitatif dan RED. Bandung: Alfabeta.

Suryabrata, Sumadi. 2005. Metodologi Penelitian. Jakarta: PT. Raja Grafindo Persada.

Syakir, Ahmad. 2014. Peran Account Officer dan Perkembangan Pembiayaan pada Perbankan Syariah". Madania. Vol. XVIII, No. 1., pp. 87-96

Tohir, Noel Chabannel. 2012. Panduan Lengkap Menjadi Acoount Officer. Jakarta: PT. Gramedia Pustaka.

Tugiman, Hiro. 2006. Standar Profesional Audit Internal. Yogyakarta: Kanisius. Undang-undang Republik Indonesia No. 13/ 2003, Tentang Ketenagakerjaan.

Undang-undang Republik Indonesia No. 21 Tahun 2008, Tentang Perbankan Syariah.

Yamin, Sofyan dan Kurniawan, Heri. 2011. Generasi Baru Mengolah Data Penelitian dengan Partial least Square Path Modeling. Jakarta: Salemba Empat. 